\title{
KEPRAKTISAN BAHAN AJAR BERBASISE-LEARNING UNTUK MATA KULIAH KALKULUS PEUBAH BANYAK 1 (KPB 1)
}

\author{
Isra Nurmai Yenti \\ Program Studi Tadris Matematika, Jurusan Tabiyah STAIN Batusangkar \\ Korespondensi: Jl. Sudirman No.137 Kuburajo, Lima Kaum, Batusangkar, Sumatera Barat \\ e-mail: nurmaiyenti@yahoo.com
}

\begin{abstract}
This research was done to see the practicability of learning material based ELearning that was developed in Kalkulus Peubah Banyak 1 (KPB 1). The practicability of this material was seen from the easiest of using this material by the students. The design of this research was research development. The research instrument was interview. The data from interview was analyzed by using descriptive analysis. Based on the analysis of interview to the students, it was known that the learning material based E-Learning that was developed was practicable in side of use, the content, and the easiest of using it.
\end{abstract}

Kata kunci: praktis, bahan ajar, e-learning.

\section{PENDAHULUAN}

$\mathrm{B}$ erdasarkan penelitian sebelumnya, yaitu Pengembangan Bahan Ajar Berbasis E-Learning untuk Mata Kuliah Kalkulus Peubah Banyak1 (Yenti, 2010) diperoleh bahwa bahan ajar berbasis e-learning telah dirancang berdasarkan tingkat kebutuhan mahasiswa. Bahan ajar ini berupa slide presentasi dengan menggunakan Microsoft Powerpoint dan maple worksheet dengan menggunakan Maple 11. Maple worksheet yang dirancang ada 6 yaitu: maple untuk elipsoid, hiperboloid satu lembar, hiperboloid dua lembar, paraboloid eliptik, paraboloid hiperbolik dan kerucut eliptik.

Bahan ajar ini di upload ke moodle yang diberi nama E-learning STAIN Batusangkar dengan alamat: http:// elearning.stainbatusangkar.ac.id/. $E$ learning ini merupakan subdomain dari web STAIN Batusangkar. Bahan ajar tersebut diperoleh mahasiswa dengan cara mahasiswa mendaftar terlebih dahulu di E-learning STAIN Batusangkar. Selanjutnya mahasiswa mendownload semua bahan ajar. Mahasiswa dapat membuka bahan ajar tadi jika pada komputer/laptop mahasiswa tersedia software Microsoft Powerpoint dan Maple 11.

Berdasarkan penelitian sebelumnya diketahui bahwa bahan ajar yang dikembangkan baru diuji sampai pada tahap validasi. Fauzan (2009: 18) mengemukakan bahwa pengembangan suatu produk harus memperhatikan beberapa quality criteria, yaitu: validity, practicalitiy/usability, dan effectiveness. Oleh karena itu, peneliti tertarik untuk melakukan penelitian lanjutan. Dalam hal ini, peneliti ingin meneliti kepraktisan dari bahan ajar berbasis $e$ learning yang telah dikembangkan pada penelitian sebelumnya sehingga pengembangan bahan ajar tersebut memenuhi quality criteria. 


\section{KAJIAN TEORI}

\section{Bahan Ajar Berbasis E-Learning}

Bahan ajar merupakan perlengkapan dalam proses pembelajaran. Bahan ajar adalah segala bentuk bahan yang digunakan untuk membantu guru/instruktur dalam melaksanakan kegiatan belajar mengajar. Bahan yang dimaksud bisa berupa bahan tertulis maupun bahan tidak tertulis (Majid, 2006: 173). Sedangkan Panen (2001: 6) menyatakan bahan ajar adalah bahanbahan atau materi perkuliahan yang disusun secara sistematis yang digunakan dosen dan mahasiswa dalam proses perkuliahan. Jadi, bahan ajar adalah adalah seperangkat materi yang disusun secara sistematis baik tertulis maupun tidak tertulis sehingga tercipta lingkungan/suasana yang memungkinkan mahasiswa untuk belajar.

Bahan ajar dapat dikelompokkan dalam beberapa kategori. Bentuk bahan ajar menurut Majid (2006: 174) adalah sebagai berikut: (1) Bahan cetak antara lain handout, buku, modul, lembar kerja siswa, brosur, leaflet, wallchart, foto/gambar, model/market; (2) Bahan ajar dengar seperti kaset, radio, piringan hitam dan compact disk audio; (3) Bahan ajar pandang dengar seperti video compact disk, film; dan (4) Bahan ajar interaktif seperti CD interaktif, computer based internet.

Jenis bahan ajar yang digunakan dalam penelitian ini adalah bahan ajar dalam bentuk computer based internet. Pembelajaran dengan computer based internet biasa disebut e-learning.

Purbo (2002: 3) menjelaskan bahwa istilah "e" atau singkatan dari elektronik dalam e-learning digunakan sebagai istilah untuk segala teknologi yang digunakan untuk mendukung usaha-usaha pengajaran lewat teknologi elektronik internet. Sedangkan Hartley dalam Wahono (2005: 2) menyatakan $e$ learning merupakan suatu jenis belajar mengajar yang memungkinkan tersampaikan bahan ajar ke siswa dengan menggunakan media internet, intranet atau media jaringan komputer lain. Berdasarkan pendapat ahli di atas dapat disimpulkan bahwa e-learning adalah pembelajaran yang memanfaatkan media elektronik atau teknologi komputer baik berupa jaringan komputer, internet maupun komputer standalone dalam proses pembelajaran.

Karakteristik dan bentuk dari bahan ajar berbasis e-learning yang telah dikembangkan (Yenti, 2010: 18-21) adalah sebagai berikut:

\section{Slide pada Microsoft Powerpoint}

Slide pada Microsoft Powerpoint dibuat interaktif, seolah-olah mahasiswa sedang kuliah tatap muka dengan dosen. Slide juga menggunakan bahasa yang sederhana dan jelas. Karakteristik isi slide pada Microsoft Powerpoint adalah sebagai berikut:

a. Indikator kompetensi

Slide memuat indikator kompetensi yang bertujuan untuk memberikan arahan kepada mahasiswa tentang tujuan pembelajaran yang akan dicapai. Jika mahasiswa mengetahui tujuan yang akan dicapai, maka mahasiswa lebih bersemangat belajar.

b. Manfaat dalam kehidupan seharihari

Slide juga memaparkan manfaat dari materi permukaan dalam ruang berdimensi tiga dalam kehidupan sehari-hari. Manfaat tersebut dipaparkan dalam bentuk pertanyaan-pertanyaan, seolaholah dosen bertanya langsung ke mahasiswa dan mahasiswa ikut terlibat dalam proses pembelajarannya. Hal ini bertujuan agar mahasiswa termotivasi belajar.

c. Materi

Materi pada slide disadur dari buku Kalkulus jilid 2 edisi 8 
karangan Edwin J. Purcell dkk. Materi diungkapkan dalam bahasa yang sederhana dan jelas. Selain itu, materi juga memuat pengembangan-pengembangan yang dapat menambah pengetahuan mahasiswa.

d. Latihan

Soal latihan dipilih dari buku pegangan mahasiswa yaitu buku Kalkulus jilid 2 edisi 8 karangan Edwin J. Purcell dkk. Pada latihan, mahasiswa diminta terlebih dahulu mengerjakannya di kertas kerja. Apabila mereka sudah selesai menjawabnya, mereka dapat mencocokkan dengan solusi yang diberikan dan melihat bentuk grafik yang sebenarnya dengan maple 11.

\section{Mapleworksheet}

Mapleworksheet merupakan alat bantu mahasiswa dalam memvisualisasikan grafik di ruang berdimensi tiga. Jika mahasiswa tidak mampu membayangkan bentuk grafik dari suatu persoalan, mahasiswa dapat menggunakan maple worksheet yang relevan, kemudian mensketsanya di kertas kerja masing-masing.

Karakteristik isi mapleworksheet adalah sebagai berikut:

a. Bentuk umum persamaan

Maple memuat bentuk umum persamaan. Hal ini bertujuan membantu mahasiswa mengingat kembali persamaan dari permukaan yang akan dibuat. Selain itu, ketika mahasiswa membuat grafik dari soal latihan yang diberikan, mahasiswa dapat meng-copy salah satu bentuk umum persamaan yang diketahui. Kemudian mahasiswa mengganti variabel-variabelnya.

b. Contoh

Maple juga berisi contoh dari salah satu bentuk umum persamaan beserta grafiknya. c. Petunjuk

Hal ini bertujuan untuk membantu mahasiswa dalam membuat grafik dari persoalan yang diberikan, karena tidak semua mahasiswa mampu menggunakan maple.

Bahan ajar berbasis e-learning dirancang untuk materi permukaan dalam ruang tiga di mata kuliah Kalkulus Peubah Banyak 1. Bahan ajar ini sudah valid menurut validator.

\section{Kepraktisan}

Kepraktisan merupakan kata benda dari praktis. Menurut Kamus Besar Bahasa Indonesia, praktis berarti mudah dan senang memakainya. Jika dikaitkan dengan bahan ajar, mahasiswa senang dan mudah menggunakan bahan ajar ini dalam pembelajaran.

Kepraktisan merupakan salah satu 'quality criteria' dari pengembangan suatu produk. Nieveen (1999: 127) menjelaskan a second characteristic of high-quality material is that teachers (and other experts) consider the material to be usable and that it is easy for teachers and students to use the materials in a way that is largely compatible with the developer's intentions. Dengan kata lain, produk yang dirancang, dalam hal ini bahan ajar, mudah digunakan oleh dosen dan mahasiswa.

Fauzan (2009: 24) mengemukakan hal-hal yang dapat diselidiki pada kepraktisan produk yaitu: keterbacaan, kemudahan dalam mengakses informasi yang dibutuhkan, struktur setiap icon, dan lain-lain. Indikator yang digunakan untuk mengukur kepraktisan ini adalah petunjuk, isi dan kemudahan penggunaan bahan ajar berbasis e-learning.

\section{METODE PENELITIAN}

Jenis penelitian yang dipakai adalah pendekatan penelitian pengembangan (development research). Pendekatan pe- 
nelitian pengembangan digunakan untuk mengukur kepraktisan bahan ajar berbasis e-learning yang telah dikembangkan sebelumnya di STAIN Batusangkar.

Kepraktisan bahan ajar diperoleh dari ujicoba terbatas pada beberapa orang mahasiswa yang telah mengambil mata kuliah KPB 1 terdiri atas 3 orang mahasiswa kelompok tinggi, 3 orang mahasiswa kelompok sedang dan 3 orang mahasiswa kelompok rendah. Data hasil wawancara dianalisis dengan menggunakan teknik deskriptif sehingga diperoleh data kepraktisan bahan ajar berbasis e-learning. Adapun komponen yang diteliti dapat dilihat pada Tabel 1 .

Tabel 1. Kepraktisan Bahan Ajar Berbasis E-learning

\begin{tabular}{|c|c|c|c|}
\hline No. & Aspek yang dilihat & $\begin{array}{c}\text { Metode } \\
\text { pengumpulan data }\end{array}$ & Instrumen \\
\hline 1. & $\begin{array}{l}\text { Petunjuk bahan ajar berbasis e-learning } \\
\text { a. Apakah petunjuk penggunaan e-learning dapat } \\
\text { dipahami dengan jelas? } \\
\text { b. Apakah petunjuk penggunaan maple untuk } \\
\text { masing-masing permukaan dapat dipahami } \\
\text { dengan jelas? }\end{array}$ & $\begin{array}{l}\text { Wawancara } \\
\text { dengan } \\
\text { mahasiswa }\end{array}$ & $\begin{array}{l}\text { Pedoman } \\
\text { wawancara }\end{array}$ \\
\hline 2. & $\begin{array}{l}\text { Isi bahan ajar berbasis e-learning } \\
\text { a. Apakah Anda paham dengan materi yang } \\
\text { terdapat pada slide power point setelah } \\
\text { membacanya? } \\
\text { b. Apakah Anda paham dengan materi yang } \\
\text { terdapat pada maple setelah menggunakannya?. } \\
\text { c. Bagaimanakah bahasa yang digunakan dalam } \\
\text { slide power point? } \\
\text { d. Apakah disain slide power point yang saya } \\
\text { rancang menarik bagi Anda? } \\
\text { e. Apakah disain maple untuk masing-masing } \\
\text { permukaan yang saya rancang menarik bagi } \\
\text { Anda? }\end{array}$ & & \\
\hline 3. & $\begin{array}{l}\text { Kemudahan penggunaan bahan ajar berbasis } e \text { - } \\
\text { learning } \\
\text { a. Apakah e-learning ini mudah digunakan? } \\
\text { b. Apakah slide power point mudah digunakan? } \\
\text { c. Apakah maple untuk masing-masing permukaan } \\
\text { mudah digunakan? } \\
\text { d. Apakah slide power point mudah di-download? } \\
\text { e. Apakah maple untuk masing-masing permukaan } \\
\text { mudah di-download? }\end{array}$ & & \\
\hline
\end{tabular}

\section{HASIL PENELITIAN}

Untuk melihat kepraktisan bahan ajar berbasis e-learningini, dilakukan uji coba pada mahasiswa yang telah mengambil mata kuliah KPB 1. Ujicoba ini dilakukan mulai dari tanggal 29 Agustus 2012 sampai dengan tanggal 7 September 2012. Mahasiswa yang menjadi subjek penelitianterdiri atas 3 orang mahasiswa kelompok tinggi, 3 orang mahasiswa kelompok sedang dan 3 orang mahasiswa kelompok rendah. Mahasiswa kelompok tinggi dipilih dari mahasiswa yang memperoleh nilai $\mathrm{A}$ atau B. Mahasiswa kelompok sedang dipilih dari mahasiswa yang memperoleh nilai C. Mahasiswa kelompok rendah dipilih dari mahasiswa yang memperoleh 
nilai D. Semua mahasiswa tersebut diminta untuk login di http:// elearning.stainbatusangkar.ac.id.

Wawancara peneliti lakukan setelah mahasiswa mendaftar di e-learning dan mempelajari bahan ajar tersebut. Hasil wawancara dengan mahasiswa menunjukkan bahwa 7 orang mahasiswa telah paham denganpetunjuk penggunaan e-learning. Berikut petikan hasil wawancaranya:

Mahasiswa A: Bisa, tetapi ada sedikit kesulitan ketika pembuatan password dan user name. Pada pembuatan password sedikit sulit $\mathrm{ka}$ rena harus menggunakan gabungan huruf kapital, huruf kecil, angka, simbol dan lain-lain.

Mahasiswa D: Petunjuk penggunaan elearning mudah untuk dipahami, dimana pada petunjuk dijelaskan dengan rinci bagaimana tahap pendaftaran untuk menjadi anggota baru sampai dengan cara login dalam e-learning.

Mahasiswa H: Dapat dipahami karena sudah dijelaskan dengan baik, tetapi pada login awal agak susah.

Berdasarkan petikan wawancara di atas, dapat disimpulkan bahwa mahasiswa sudah paham dengan petunjuk penggunaan e-learning. Namun, mahasiswa memerlukan tambahan informasi cara membuat password karena terdiri dari beberapa karakter yang berbeda.

Petunjuk penggunaan Maple untuk masing-masing permukaan dapat dipahami dengan jelas. Ada 5 orang mahasiswa yang memberikan komentar tentang hal tersebut. Sedangkan 4 mahasiswa lainnya mengomentari cukup dapat memahami karena mereka terkendala dengan loading Maple yang lama dan petunjuk tidak bereaksi pada langkah 4 dan seterusnya. Berikut beberapa petikan wawancaranya:

Mahasiswa A: Sedikit dapat dipahami dan dalam penggunaan Maple membutuhkan kesabaran yang ekstra, karena loadingnya lama atau mungkin program Maple terlalu berat untuk netbook.

Mahasiswa B: Cukup dapat dipahami, saya dapat mengikuti petunjuk dengan baik. Akan tetapi dibutuhkan kesabaran dalam penggunaannya karena program Maple tersebut loadingnya lama.

Mahasiswa E: Petunjuk penggunaan Maple mudah dipahami.

Mahasiswa H: Dapat dipahamidengan jelas, karena bahasanya mudah dipahami. Tetapi pada penggunaan $3 D$ tidak jalan sehingga gambar tidak bisa dilihat.

Jadi, petunjuk penggunaan Maple untuk masing-masing permukaan dapat dipahami dengan jelas. Namun, diperlukan perbaikan pada langkah 4 tentang 3D dan jenis Maple yang prosesnya cepat untuk netbook.

Materi yang terdapat pada slide power point dapat dipahami mahasiswa dengan baik. Menurut mereka, masingmasing permukaan digambarkan dengan jelas beserta bentuk persamaannya dan cara menggambarnya. Selain itu, ada diberikan soal dan pembahasannya. Berikut hasil wawancaranya:

Mahasiswa B: Dapat dipahami, karena setiap permukaan diberi contoh dan cara penyelesaiannya juga jelas.

Mahasiswa D: Materi yang terdapat pada slide dapat dipahami. Bahasa yang digunakan edukatif. Masing-masing permukaan 
digambarkan dengan jelas beserta bentuk persamaannya dan cara menggambarnya.

Mahasiswa I: Materinya dapat dipahami, karena materi yang disajikan sangat detail berupa langkah-langkah, bentuk persamaan dan grafik dari persamaan tersebut.

Materi yang terdapat pada maple dapat dipahami mahasiswa. Hal ini berdasarkan komentar mahasiswa kelompok tinggi, 1 orang mahasiswa kelompok sedang dan 1 orang mahasiswa kelompok rendah. Mahasiwa yang terkendala dengan materi pada maple mengomentari bahwa mereka masih membutuhkan arahan dari dosen untuk menafsirkan gambar. Berikut petikan wawancaranya.

Mahasiswa F: Cukup sulit karena menurut saya masih dibutuhkan arahan dari dosen terutama menafsirkan gambar agar tidak salah persepsi.

Bahasa yang digunakan dalam slide power point mudah dipahami mahasiswa. Menurut mereka, bahasanya sederhana, tidak berbelit-belit dan komunikatif. Beberapa hasil wawancara menyatakan berikut ini:

Mahasiswa C: Bahasa yang digunakan mudah dimengerti karena di slide power point menggunakan bahasa yang menuntun untuk melakukan langkah-langkah kerjanya.

Mahasiswa D: Bahasanyamudah dipahami, sederhana, tidak berbelit-belit dan komunikatif.

Mahasiswa I : Mudah dipahami dan komunikatif.
Disain slide power pointdan maple worksheetmenarik bagi maha-siswa. Kombinasi warna yang digunakan bagus. Namun, gambar pada slide power point tidak dapat digerakkan sehingga mahasiswa menyarankan untuk ditambah animasinya. Berikut petikan wawancaranya:

Mahasiswa B: Disain slidelumayan menarik. Tetapi, disain ini akan lebih menarik lagi kalau gambar-gambar tersebut bisa bergerak. Sedangkan disain maple menarik karena gambar tiap-tiap permukaannya jelas

Mahasiswa D: Disain slidenya cukup menarik dengan menampilkan gambar sehingga menimbulkan ketertarikan mahasiswa untuk membacanya. Walaupun backgroundnya sederhana, tapi kombinasi warna yang digunakan sangat bagus. Sedangkan disain maplenya lumayan menarik dengan perpaduan warna pada setiap gambar permukaan.

E-learning ini mudah digunakan. Ada 5 orang mahassiwa yang mengungkapkan seperti itu, yaitu 2 orang mahasiswa kelompok tinggi, 2 orang mahasiswa kelompok sedang dan 1 orang mahasiswa kelompok rendah. Mahasiswa menemui kendala dalam membuat password, software Maple yang lambat dan harus diinstal dulu di beberapa komputer. Berikut cuplikan wawancaranya:

Mahasiswa A: Mudah tetapi ada sebagian komputer tidak memiliki program Maple sehingga tidak bisa dibuka.

Mahasiswa D: Mudah digunakan, tapi saya sedikit kesulitan 
pada proses pendaftaran

di bagian pembuatan

password, karena syarat pembuatan passwaord terlalu banyak dan menggunakan petunjuk dalam bahasa Inggris.

Mahasiswa H: Mudah, karena petunjuknya sangat jelas.

Semua mahasiswa mengatakan bahwa slide power point mudah digunakan karena sudah biasa digunakan dalam perkuliahan sehari-hari. Sedangkan 6 orang mahasiswa mengatakan bahwa maple worksheet susah digunakan karena belum terbiasa dengan program Maple 11, langkah-langkah penggunaan Maple yang tidak jalan, dan loading-nya yang lama.

Mahasiswa A : Cukup sulit, karena saya belum biasa menggunakan program tersebut dan loadingnya juga lama.

Mahasiswa C : Tidak bisa digunakan untuk 3D-implicit plot -> $x, y, z$, hanya bisa untuk $2 D$.

Mahasiswa D : Tidak, petunjuk penggunaannya sulit diaplikasikan pada Maple 14 Classic Worksheet.

Mahasiswa I : Tidak, karena terkendala pada langkah penggunaannya.
Tujuh orang mahasiswa mengemukakan bahwa slide power pointdan maple worksheetmudah didownload. Menurut mereka ukurannya tidak terlalu besar dan tidak ada kendala dalam mendownloadnya. Berikut beberapa petikan wawancaranya:

Mahasiswa B : Sangat mudah didonwload dan saya tidak mengalami kesulitan dalam mendownloadnya.

Mahasiswa D : Mudah, karena ukurannya tidak terlalu besar.

Mahasiswa H : Mudah, karena memorinya tidak terlalu besar dan tidak ada masalah dalam mendownloadnya.

Berdasarkan hasil wawancara dengan mahasiswa di atas diperoleh bahwa bahan ajar berbasis e-learning sudah praktis baik dari segi petunjuk penggunaan, isi bahan ajar, dan kemudahan penggunaannya. Namun, mahasiswa masih terkendala pada penggunaan maple worksheet untuk masing-masing permukaan. Petunjuk penggunaan, isi dan kemudahan penggunaan maple perlu diperbaiki.

Maple worksheet dibuat dalam program Maple 14 Classic Worksheet. Salah satu contoh maple worksheet yang telah direvisi dapat dilihat pada Gambar 1, Gambar 2 dan Gambar 3. 


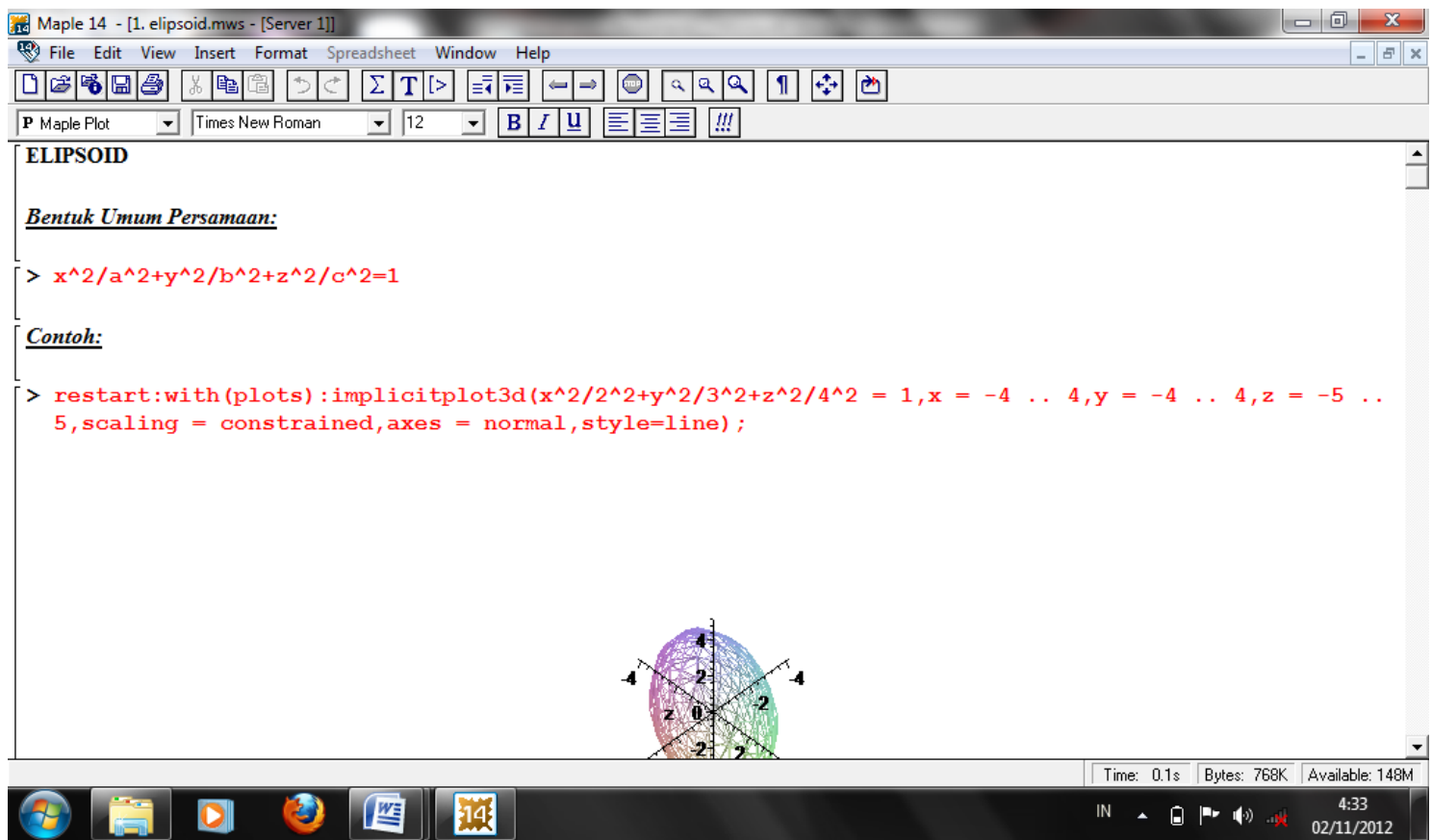

\section{Gambar 1}

10 Maple 14 - [1. elipsoid.mws - [Server 1]

19. File Edit View Insert Format Spreadsheet Window Help

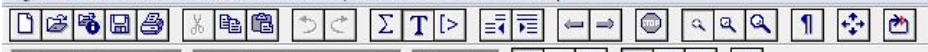

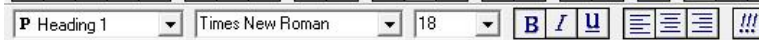

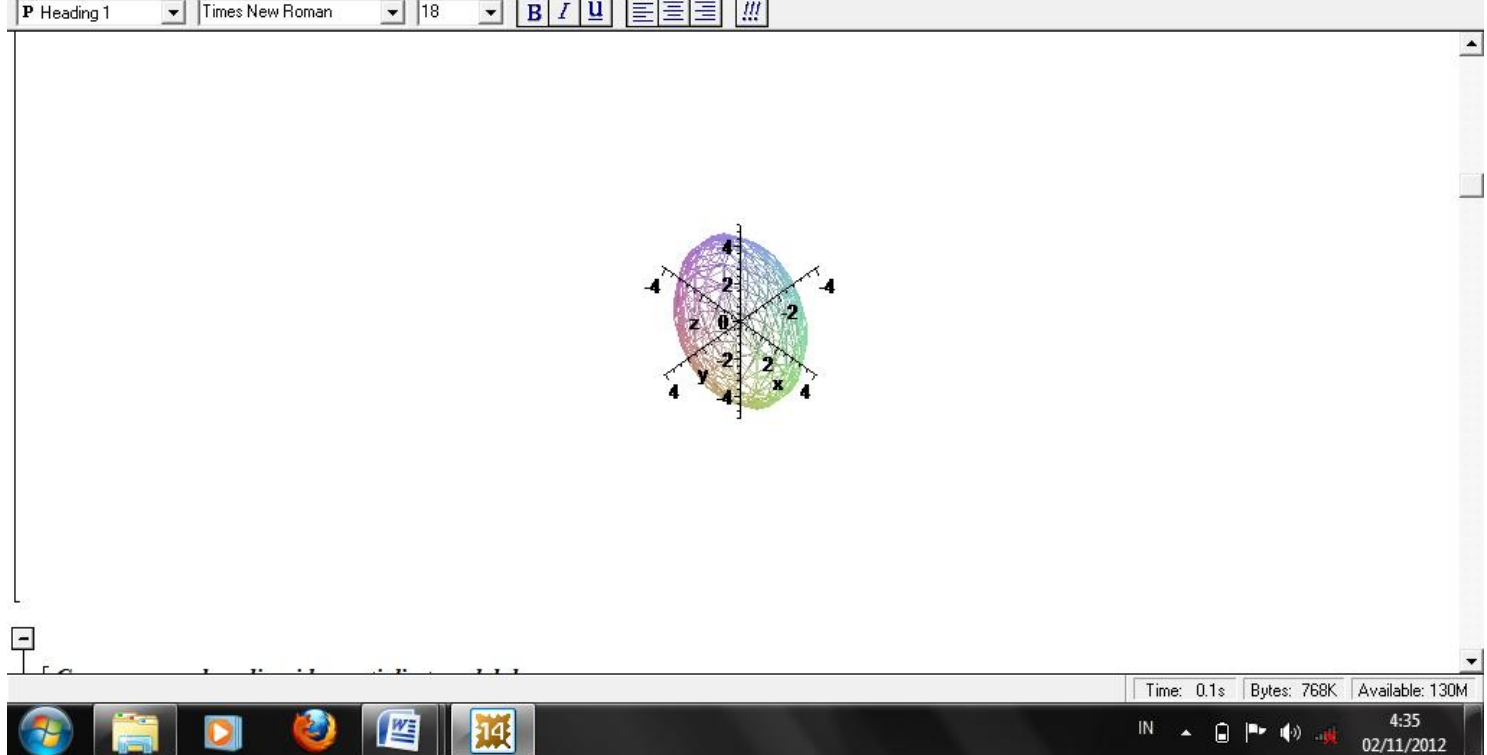

Gambar 2 


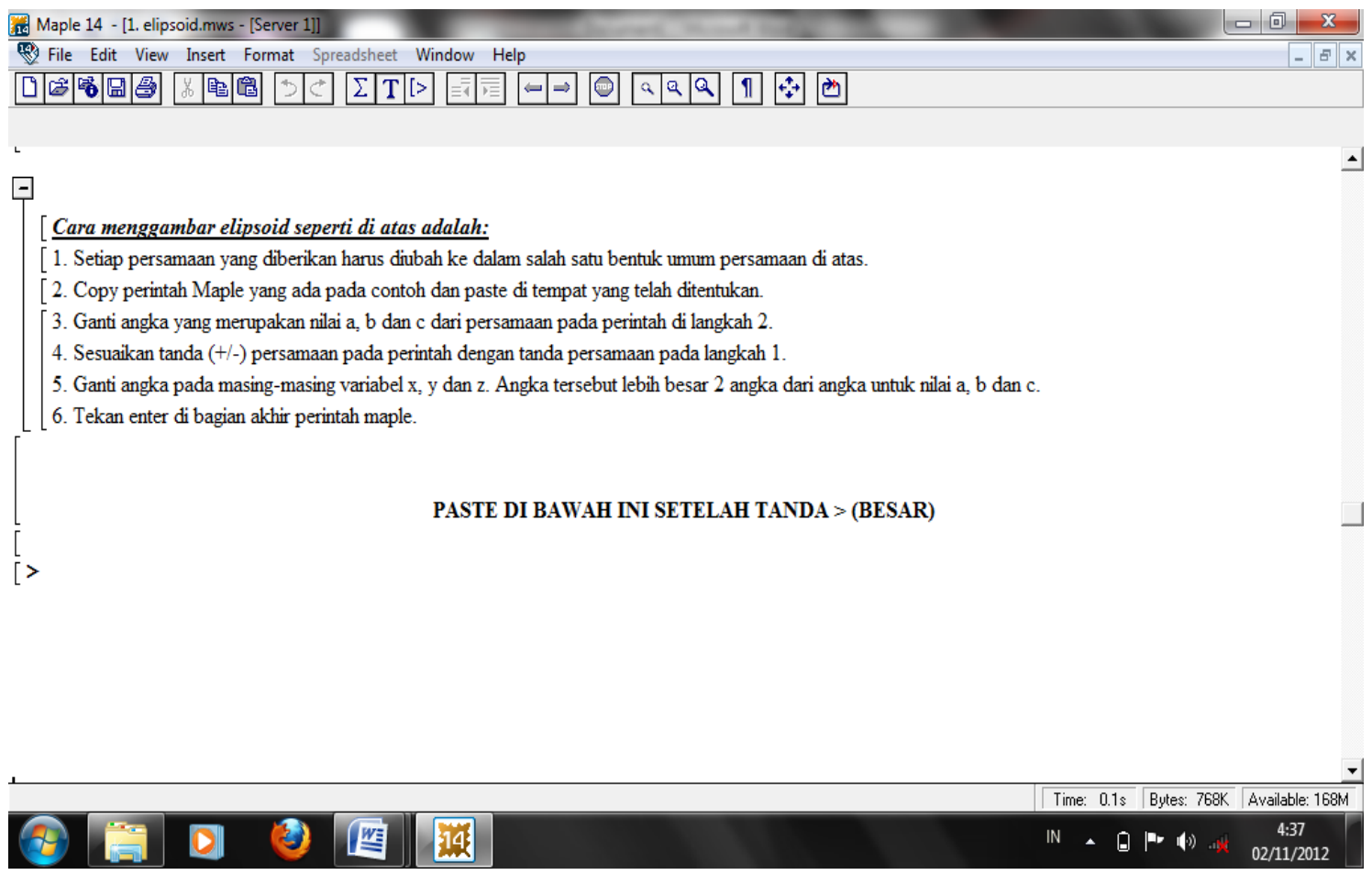

Gambar 3

\section{PEMBAHASAN}

Berdasarkan hasil wawancara peneliti dengan mahasiswa tentang kepraktisan bahan ajar berbasis e-learning, diperoleh gambaran sebagai berikut:

1. Mahasiswa sudah paham dengan petunjuk penggunaan e-learning. $\mathrm{Na}$ mun, mahasiswa memerlukan tambahan informasi cara membuat password karena terdiri dari beberapa karakter yang berbeda.

2. Petunjuk penggunaan Maple untuk masing-masing permukaan dapat dipahami dengan jelas. Namun, diperlukan perbaikan pada langkah 4 tentang 3D dan jenis Maple yang prosesnya cepat untuk netbook.

3. Materi yang terdapat pada slide power point dapat dipahami mahasiswa dengan baik.

4. Materi yang terdapat pada maple dapat dipahami mahasiswa.

5. Bahasa yang digunakan dalam slide power point mudah dipahami mahasiswa. Hal ini sesuai dengan pendapat Rusman (2010: 376) yaitu seyogya- nya bahan ajar tersebut dibuat sedemikian rupa sehingga terjadi dialog atau interaksi antara bahan ajar dengan mahasiswa. Interaksi dan dialog ini juga dapat diciptakan dengan penggunaan bahasa yang komunikatif.

6. Disain slide power pointdan maple worksheetmenarik bagi mahasiswa. Kombinasi warna yang digunakan bagus.

7. E-learning ini mudah digunakan. Sebagaimana Purbo (2002: 10) mengemukakan sistem yang paling disukai adalah sistem yang sederhana, mudah, dan menarik digunakan.

8. Semua mahasiswa mengatakan bahwa slide power point mudah digunakan karena sudah biasa digunakan dalam perkuliahan sehari-hari. Sedangkan 6 orang mahasiswa mengatakan bahwa maple worksheet susah digunakan karena belum terbiasa dengan program Maple 11, langkah-langkah penggunaan Maple yang tidak jalan, dan loading-nya yang lama. 
9. Mahasiswa mengemukakan bahwa slide power pointdan maple worksheetmudah di-download.

Faktor yang menjadi kendala bagi mahasiswa dalam melaksanakan pembelajaran dengan bahan ajar berbasis $e$ learning adalah:

1. Mahasiswa memerlukan tambahan informasi cara membuat password karena terdiri dari beberapa karakter yang berbeda.

2. Tidak semua komputer atau laptop atau netbook memiliki program Maple 11 sehingga mahasiswa terlebih dahulu harus menginstalnya.

3. Program Maple 11 tidak jalan pada Windows 7. Hal ini sesuai dengan komentar di www.maplesoft.com yaitu the form to retrieve an updated version of Maple 11 with Vista support is no longer available. Beginning with version 12, Maple now fully supports both the 32 and 64-bit versions of Windows Vista.

4. Ketika mahasiswa membuka maple worksheet untuk masing-masing permukaan di Maple 14 Classic Worksheet, petunjuk yang diberikan tidak

\section{DAFTAR RUJUKAN}

Fauzan, Ahmad. 2009. Kumpulan Slide Penelitian Pengembangan. Materi Kegiatan Workshop Metodologi Penelitian Aplikatif Dosen. STAIN Batusangkar. 19, 20, dan 31 Desember 2009.

Majid, Abdul. 2006. Perencanaan Pembelajaran: Mengembangkan Standar Kompetensi Guru. Bandung: Remaja Rosdakarya.

Nieveen, Nienke. 1999. Design Approaches and Tools in Education and Training. ada pada Maple 14 Classic Worksheet.

\section{PENUTUP}

Setelah melalui suatu prosedur penelitian, hasil kepraktisan berdasarkan wawancara dengan mahasiswa menunjukkan bahwa bahan ajar berbasis $e$ learning yang dikembangkan sudah praktis dari segi petunjuk penggunaan, isi bahan ajar, dan kemudahan penggunaannya. Data kepraktisan yang diperoleh pada penelitian ini hanya dalam bentuk deskriptif, bagi peneliti yang ingin melakukan penelitian tentang kepraktisan suatu produk disarankan menggabungkan data kualitatif dan kuantitatif.

Peneliti juga menyarankan kepada dosen untuk memberikan perkuliahan tentang penggunaan Maple atau memasukkan materi Maple ke dalam mata kuliah Aplikasi Komputer sehingga mahasiswa terampil menggunakan software ini.Penelitian selanjutnya yang akan menggunakan Maple di netbook, diharapkan mencari versi baru yang lebih cepat prosesnya di netbook atau mengubahnya ke dalam Maple.

Dordrecht: Kluwer Academic Publishers.

Purbo, Onno W. 2002. Teknologi Elearning Berbasis PHP dan MySQL. Jakarta: PT. Elex Media Komputindo.

Panen, Paulina dan Purwanto. 2001. Penelitian Bahan Ajar. Jakarta: PAU-PPAI, Universitas Ter-buka.

Rusman. 2010. Model-Model Pembelajaran Mengembangkan Profesional Guru. Jakarta: Rajawali Pers. 
Wahono, Romi Satria. 2005. Pengantar

E-Learning dan Pengembangannya. (Online), (Portal www.ilmukomputer.com

Indonesia, diakses 22 Agustus 2010).

www.maplesoft.com.
Yenti, Isra Nurmai. 2010. "Pengembangan Bahan Ajar Berbasis ELearning untuk Mata Kuliah Kalkulus Peubah Banyak 1 (KPB 1) di STAIN Batusangkar". Laporan Penelitian tidak diterbitkan. Batusangkar: STAIN Batusangkar. 